\title{
Um sonho bom
}

Natally Nobre ${ }^{1}$

Falar da Vernáculo é falar de um sonho bom de um grupo de amigos que se tornou realidade. Tomei contato com a Vernáculo em 2005 quando ingressei na graduação de História: Semana do calouro, apresentação do curso e dos grupos de pesquisa e Jonas Pegoraro, com cara de cansado explicando a proposta da Revista. Uma Revista discente com o propósito de divulgar a produção dos alunos: ótimas pesquisas que ficavam restritas a estes e seus orientadores.

Segundo semestre novamente o Jonas pedindo aos calouros que se interessassem para marcar uma reunião e passar as atividades da Revista. Muito bem, por que não? Reuni os amigos, muito mais veteranos do que aluno do meu ano, e fomos ver o que era preciso. Muito mais do que o esperado. A revista estava há muitos números atrasada. Fazendo as contas dos artigos aceitos e ainda não publicados não seria suficiente.

A próxima novidade foi descobrir que não conseguiríamos versão impressa de nada. A Revista não tinha dinheiro. Tentamos captar recursos de todos os lados e tudo o que conseguimos foi o conselho de

\footnotetext{
${ }^{1}$ Graduada em História, UFPR, professora da rede estadual (PR) de ensino.
} 
partir para a versão online. Pareceu um falso consolo no momento, mas a partir de então começou a odisseia ISSN online. Passei mais tempo no setor de Revistas da Universidade pedindo orientação ao Paulo do que nos happy hours nestes dias.

Entre idas e vindas conseguimos o reconhecimento da Revista pelo Curso, feito isso, Barleta se encarregou de toda a papelada a ser enviada para o registro oficial da Revista junto à Biblioteca Nacional enquanto eu fiz o curso para lidar com a Plataforma SER. Papelada burocrática resolvida, revista virtual registrada, e seu lugar vazio estava pronto para ser ocupado no SER.

Alguns integrantes se foram, outros vieram e a nova Odisseia foi deixar a Revista em dia. Isso incluiu diagramar os artigos ainda não publicados e disponibilizar online os antigos. Foi uma caça ao tesouro pelos antigos números, soterrados no depósito do departamento. Muitas tardes divertidas achando coisas do Arco da Velha com o Serginho e a Marilena, secretários do Departamento e do Curso.

Participação em Semanas Acadêmicas, divulgação em outras faculdades, recebimento e trato dos artigos que começaram a fluir, finalmente a Revista voltou a andar. Em 2010 ela finalmente estava periodizada e estruturada. Mas nós estávamos nos formando, o que aconteceria depois? O ciclo não se repetiu. Antes que saíssemos um novo grupo tomou o editorial da Revista, e agora estou aqui em breves linhas contando um pouco da Odisseia da Revista para manter-se viva. 
Houve percalços ao longo dos trabalhos, mas eles são irrelevantes perto do que conseguimos. A Revista não se extinguiu, tem sua classificação digna na CAPES, e se há quem torça o nariz e a encare como concorrência, isso só infla o orgulho de todos que perderam tantas sextas-feiras ensolaradas na frente do computador organizando os números e os colocando no ar. 